\title{
An efficient synthesis of pyrazolo[1,5-a]pyrimidines and evaluation of their antimicrobial activity
}

\author{
SOMESHWAR DESHMUKH, KUNAL DINGORE, VISHWAS GAIKWAD and \\ MADHUKAR JACHAK* \\ Organic Chemistry Research Center, Department of Chemistry, K T H M College, Affiliated to Savitribai \\ Phule Pune University, Gangapur Road, Nashik, Maharashtra 422 002, India \\ e-mail:mnjachak@hotmail.com; someshwardeshmukh@gmail.com
}

MS received 15 November 2015; revised 13 July 2016; accepted 13 July 2016

\begin{abstract}
A series of new pyrazolo[1,5- $a$ ]pyrimidine derivatives has been synthesized by using 7-hydrazinyl5-methylpyrazolo[1,5- $a$ ]pyrimidine-3-carbonitrile 1 and 7-amino-5-methylpyrazolo[1,5- $a$ ]pyrimidine-3-carbonitrile $\mathbf{2}$ as precursors. The pyrazolo[3,4- $d$ ] pyrimidines $\mathbf{3 a - b}$ have been synthesized by a three-step reaction starting with $\mathbf{1}$. Compound $\mathbf{1}$ was utilized for the synthesis of dioxopyrrolidindolinylamio-pyrazolo-pyrimidines $\mathbf{4 a - b}$, and dioxoisoindolin-pyrazolo-pyrimidines $\mathbf{4 c - d}$. Also, compounds 4a-d were synthesized using deep eutectic solvents (DES). This method using DES provides several advantages such as benign environment, high yield, scalable and simple work-up procedure. Similarly, the cyclocondensation of $\mathbf{2}$ with $\alpha$-acetyl$\gamma$-butyrolactone afforded pyrazolo-pyrido-pyrimidine $\mathbf{5}$ and dihydrofuro-pyrido-pyrazolo-pyrimidine $\mathbf{6}$. All synthesized compounds were screened for antimicrobial activity.
\end{abstract}

Keywords. Pyrazolo-pyrimidine; pyrazolyl-pyrazolo-pyrimidine; deep eutectic solvents; DES; $\alpha$-acetyl- $\gamma$-butyrolactone.

\section{Introduction}

As analogues of purine, pyrazolo[1,5- $a$ ]pyrimidines have attracted chemists owing to their biological and pharmacological importance such as hypnotic, ${ }^{1}$ antiinflammatory, ${ }^{2}$ anti-tumor, ${ }^{3-7}$ antimycobacterial, ${ }^{8}$ antiviral, ${ }^{9-11}$ antitrypanosomal, ${ }^{12}$ antischistosomal, ${ }^{13}$ and most importantly anti-tumor activity. ${ }^{14-17}$ Literature survey revealed that Zaleplon is an ideal hypnotic drug which was structural mimic to the pyrazolo[1,5- $a$ ]pyrimidine and has generated a lot of interest in the pyrazolo[1,5- $a$ ]pyrimidine derivatives. ${ }^{18}$

In the literature, it was also found that not only the core moieties showed biological activity but also the additional ring annulated system, namely, hydrazine annulated pyrazolo[3,4- $d]$ pyrimidines, ${ }^{19}$ dioxo dihydroisoindols, dioxo dihydropyrrols, ${ }^{20}$ pyrazoles, ${ }^{21}$ also exhibited diverse spectrum of biological activities. However, the synthesis and bioactivity of amino and hydrazone derivative of pyrazolo[1,5- $a$ ]pyrimidine is limited..$^{22,23}$

Synthesis of the above stated target compounds suffer from limitations that include use of toxic reagents, volatile solvents or expensive catalysts. The reaction conditions were harsh in most of the protocols and

\footnotetext{
*For correspondence
}

tedious work-up procedures in a few cases. Therefore, efficient protocol for the synthesis of hydrazineannulated dioxo pyrrolidones and pyrazolones under milder conditions and in an environmentally benign manner is needed.

Deep eutectic mixtures belong to an interesting set of eutectics which have been recently explored in important organic reactions. ${ }^{24,25}$ Deep eutectic solvents (DESs) are the special type of ionic solvents composed of quaternary salt like choline chloride $(\mathrm{ChCl})$ and neutral molecules like urea, glycerol, etc. The melting point of such mixtures is much lower when compared with either of the individual components. ${ }^{26}$ Although they are somewhat similar in features to conventional ionic liquids, their advantages are due to the major differences between them. The eutectics are cost effective, non-toxic and easy to store than most ionic liquids owing to the fact that choline is a naturally occurring bio-compatible compound and choline chloride is also commercially produced on a large scale as a chicken feed additive. For this reason, DESs gain increasing attention in synthetic organic chemistry and industry. This also offers several benefits, including negligible vapour pressure, non-flammability, chemical/thermal stability, and non-reactivity towards water.

To address this problem and as a continuation of our work towards the synthesis of nitrogen containing 
heterocycles, ${ }^{27,28}$ we intended to develop a convenient synthetic approach for the synthesis of new pyrazolo $[1,5-a]$ pyrimidine annulated heterocycles.

\section{Experimental}

\subsection{Reagents}

Reactions were monitored by thin layer chromatography (TLC), carried out on $0.2 \mathrm{~mm}$ silica gel $60 \mathrm{~F}_{254}$ precoated (Merck) plates using UV light (254 and $366 \mathrm{~nm}$ ) for detection. Compounds were purified by column chromatography using silica gel of 5-20 $\mu \mathrm{m}$ (Merck, 60-120 mesh). Column dimension was $39 \times 2 \mathrm{~cm}$ and elution volume used was about $200-400 \mathrm{~mL}$ for each product. Common reagent grade chemicals were either commercially purchased and used without further purification or were prepared by standard literature procedures.

\subsection{Characterization}

Melting points were determined on a Gallenkamp melting point apparatus. The ${ }^{1} \mathrm{H}$ NMR $(300 \mathrm{MHz})$ and ${ }^{13} \mathrm{C}$ NMR $(75 \mathrm{MHz})$ spectra were recorded on a Varian XL300 spectrometer. Chemical shifts are reported in ppm relative to tetramethylsilane (TMS), and multiplicities are given as s (singlet), bs (broad singlet), d (doublet), $\mathrm{t}$ (triplet), q (quartet), and $\mathrm{m}$ (multiplet). Infrared spectra were recorded as $\mathrm{KBr}$ pellets on a Shimadzu FTIR408 spectrophotometer. Mass spectra were recorded on a Shimadzu LC-MS: EI QP 2010A mass spectrometer with ionization potential $70 \mathrm{eV}$. Elemental analyses were performed on Thermo Quest Flash 1112 Series EA analyzer.

\subsection{Preparation of deep eutectic mixture (DES) from choline chloride and urea}

In this study, deep eutectic solvent (DES) was synthesized according to the procedures reported the literature (Figure 1). ${ }^{30}$ The preparation involved reaction of choline chloride $1(1 \mathrm{~mol})$ with urea $2(2 \mathrm{~mol})$ at $74^{\circ} \mathrm{C}$ till a clear solution was obtained which was used for reactions without any purification. This method gave deep eutectic solvent with $100 \%$ atom economy since it completely forms a eutectic mixture without by-product formation. Also, other eutectic mixtures were synthesized in a similar manner. The recovery and recycling of deep eutectic solvent is given in Table 1.

\subsection{Synthesis and characterization of compounds}

2.4a Synthesis of compound 7-Hydrazinyl-5-methylpyrazolo[1,5-a]pyrimidine-3-carbonitrile 2: A solution of 7-chloro-5-methylpyrazolo[1, 5-a]pyrimidine-3-carbonitrile (1) $(0.192 \mathrm{~g}, 0.001 \mathrm{~mol})$ and hydrazine hydrate $(0.100 \mathrm{~g}, 0.002 \mathrm{~mol})$ in ethanol $(10 \mathrm{~mL})$ was stirred at room temperature for $10 \mathrm{~min}$. After completion of the reaction (Monitored by TLC using dichloromethane: methanol 9:1), reaction mixture was poured in ice cold water $(10 \mathrm{~mL})$ and further stirred for one hour. The solid obtained was suction filtered, washed with water, dried and purified by column chromatography (eluted with $1 \%$ methanol in dichloromethane) to obtain 2 . Colorless solid; yield -0.172 g, $92 \%$; M.p. $259-261^{\circ} \mathrm{C}$; IR (KBr): 3591, 3321, 3267, 3037, 2981, 2219, $1600 \mathrm{~cm}^{-1}$; ${ }^{1} \mathrm{H}$ NMR data (DMSO- $\left.d_{6}\right): \delta 2.45\left(\mathrm{~s}, 3 \mathrm{H}, \mathrm{Ar}-\mathrm{CH}_{3}\right), 4.82$ (bs, 2H, $-\mathrm{NH}_{2}$ ), 6.55 (s, 1H, Ar-H), 8.55 (s, 1H, Ar-H), 9.56 (bs, $1 \mathrm{H},-\mathrm{NH}) ;{ }^{13} \mathrm{C}$ NMR data (DMSO- $\left.d_{6}\right): \delta$ 24.4, 77.2, 88.5, 114.4, 146.3, 149.2, 150.5, 162.3; MS $(\mathrm{m} / \mathrm{z}): 189(\mathrm{M}+1,100 \%)$; Anal. Calcd. (\%) For $\mathrm{C}_{8} \mathrm{H}_{8} \mathrm{~N}_{6}$ (188.19): C, 51.06; H, 4.28; N, 44.66; Found (\%) C, $51.25 ; \mathrm{H}, 4.46 ; \mathrm{N}, 44.48$.

2.4b Synthesis of 7-Azido-5-methylpyrazolo[1,5-a]pyrimidine-3-carbonitrile (3): To a solution of compound $1(0.192 \mathrm{~g}, 0.001 \mathrm{~mol})$ in dimethyl formamide $(5 \mathrm{~mL})$, sodium azide $(0.065 \mathrm{~g}, 0.001 \mathrm{~mol})$ was added portionwise at $0-5^{\circ} \mathrm{C}$ and stirred for $30 \mathrm{~min}$. After completion of the reaction (TLC check with dichloromethane/

Table 1. The yield and recycling of deep eutectic solvent.

\begin{tabular}{lc}
\hline Entry & Yield $^{\mathrm{b}}$ \\
\hline Fresh & 92 \\
I & 91 \\
II & 90 \\
III & 92 \\
\hline
\end{tabular}

${ }^{\mathrm{a}}$ Reaction carried at $50-60{ }^{\circ} \mathrm{C}$; ${ }^{\mathrm{b}}$ Isolated Yields.

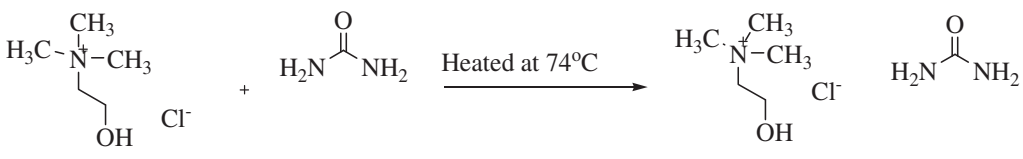

choline chloride 1 (mole) urea 2 ( moles)

Deep eutectic solvent

Figure 1. Preparation of deep eutectic mixture (DES). 
methanol 9:1), the reaction mixture was poured in ice cold water $(10 \mathrm{~mL})$ and stirred for two hours. The solid obtained was suction filtered, washed with water, dried and purified by column chromatography (eluting with $1 \%$ methanol in dichloromethane) to furnish compound 3. Brown solid; yield-0.163 g, $82 \%$; M.p. $149-151^{\circ} \mathrm{C}$; IR (KBr): 3039, 2225, 2150, 1623, $1544 \mathrm{~cm}^{-1} ;{ }^{1} \mathrm{H}$ NMR data $\left(\mathrm{CDCl}_{3}\right): \delta 2.69$ (s, 3H, Ar- $\left.\mathrm{CH}_{3}\right), 6.59$ (s, 1H, Ar-H), 8.34 (s, 1H, Ar-H); MS (m/z): $199\left(\mathrm{M}^{+}, 100 \%\right)$; Anal. Calcd. (\%) For $\mathrm{C}_{8} \mathrm{H}_{5} \mathrm{~N}_{7}$ (199.17): C, 48.24; H, 2.53; N, 49.23; Found (\%) C, 48.31; H, 2.61; N, 49.26.

2.4c Synthesis of 7-Amino-5-methylpyrazolo[1, 5-a]pyrimidine-3-carbonitrile (4): A solution of compound 3 $(0.199 \mathrm{~g}, 0.001 \mathrm{~mol})$ and sodium dithionite $(0.174 \mathrm{~g}$, $0.001 \mathrm{~mol})$ in dry methanol $(10 \mathrm{~mL})$ was heated under reflux at $70^{\circ} \mathrm{C}$ for $90 \mathrm{~min}$. After completion of the reaction (TLC check with dichloromethane/methanol 9:1) the reaction mixture was poured in ice cold water $(10 \mathrm{~mL})$ and further stirred for one hour. The solid obtained was suction filtered, washed with water, dried and purified by column chromatography (eluting with $1 \%$ methanol in dichloromethane) to furnish compound 4. Yellow solid; yield-0.140 g, $81 \%$; M.p. $276-278^{\circ} \mathrm{C}$; IR (KBr): 3337, 3332, 2904, 2227, $1600 \mathrm{~cm}^{-1} ;{ }^{1} \mathrm{H}$ NMR data (DMSO- $\left.d_{6}\right): \delta 2.40\left(\mathrm{~s}, 3 \mathrm{H}, \mathrm{Ar}-\mathrm{CH}_{3}\right), 6.18$ (s, 1H, Ar-H), 8.14 (bs, 2H, $-\mathrm{NH}_{2}$ ), 8.55 (s, 1H, Ar-H); ${ }^{13} \mathrm{C}$ NMR (DMSO- $d_{6}$ ): $\delta 24.1,77.3,90.6,114.5,146.4$, 148.3, 150.7, 162.0; MS (m/z): $173\left(\mathrm{M}^{+}, 100 \%\right)$; Anal. Calcd. (\%) For $\mathrm{C}_{8} \mathrm{H}_{7} \mathrm{~N}_{5}$ (173.17): C, 55.48; H, 4.07; N, 40.44; Found (\%) C, 55.74; H, 4.22; N, 40.68.

2.4d Synthesis of ethyl 5-amino-1-(3-cyano-5-methylpyrazolo[1,5-a]pyrimidin-7-yl)-1H-pyrazole-4-carboxylate (6): To a solution of compound 2 (0.188 g, $0.001 \mathrm{~mol})$ in ethanol $(10 \mathrm{~mL})$, ethoxymethylenecyanoacetate solution $(0.169 \mathrm{~g}, 0.001 \mathrm{~mol})$ in ethanol $(10 \mathrm{~mL})$ was added dropwise over the period of 10 minutes. Then the reaction mixture was refluxed for three hours. After completion of the reaction (TLC check with dichloromethane/methanol 9:1) the reaction mixture was poured in ice cold water $(10 \mathrm{~mL})$. The solid obtained was suction filtered, washed with water, dried and recrystallized from acetonitrile to afford compound 6 as colorless solid. Colorless solid; yield-0.295 g, 95\%; M.p. $302-304^{\circ} \mathrm{C}$; IR (KBr): $3325,3299,2904$, $2221,1709,1610 \mathrm{~cm}^{-1} ;{ }^{1} \mathrm{H}$ NMR data $\left(\mathrm{CDCl}_{3}\right): \delta 1.35$ $\left(\mathrm{t}, J=7.5 \mathrm{~Hz}, 3 \mathrm{H}, \mathrm{CH}_{3}\right), 2.77\left(\mathrm{~s}, 3 \mathrm{H}, \mathrm{Ar}-\mathrm{CH}_{3}\right), 4.32$ $\left(\mathrm{q}, J=7.8 \mathrm{~Hz}, 2 \mathrm{H}, \mathrm{CH}_{2}\right), 6.66\left(\mathrm{~s}, 2 \mathrm{H},-\mathrm{NH}_{2}\right), 7.29$ (s, $1 \mathrm{H}, \mathrm{Ar}-\mathrm{H}), 7.99$ (s, 1H, Ar-H), 8.44 (s, $1 \mathrm{H}, \mathrm{Ar}-\mathrm{H}) ;{ }^{13} \mathrm{C}$ NMR data (DMSO- $\left.d_{6}\right): \delta 14.4,24.4,59.0,81.2,93.3$, 110.3, 113.1, 139.4, 143.1, 147.2, 151.1, 152.2, 162.8, 165.1; MS (m/z): $312(\mathrm{M}+1,100 \%)$; Anal. Calcd. (\%)
For $\mathrm{C}_{14} \mathrm{H}_{13} \mathrm{~N}_{7}$ (311.3): C, 54.02; $\mathrm{H}, 4.21 ; \mathrm{N}, 31.50$; Found (\%) C, 53.75; H, 4.29; N, 31.81 .

2.4e Synthesis of 7-(5-Amino-4-cyano-1H-pyrazol-1yl)-5-methylpyrazolo[1,5-a]pyrimidine-3-carbonitrile (8): To a solution of compound $2(0.188 \mathrm{~g}, 0.001 \mathrm{~mol})$ in ethanol, $(10 \mathrm{~mL})$ ethoxymethylenmalonitrile $(0.122 \mathrm{~g}$, $0.001 \mathrm{~mol})$ in ethanol $(10 \mathrm{~mL})$ was added dropwise over the period of $10 \mathrm{~min}$. Then the reaction mixture was refluxed for six hours. After completion of the reaction (TLC check with dichloromethane/methanol 9:1) the reaction mixture was poured in ice cold water $(10 \mathrm{~mL})$. The solid obtained was suction filtered, washed with water, dried and recrystallized from acetonitrile afforded compound 8. Yellow solid; yield-0.248 g, 94\%; M.p. $333-335^{\circ} \mathrm{C}$; IR (KBr): 3406, 3336, 2914, 2237 , $2219,1600 \mathrm{~cm}^{-1} ;{ }^{1} \mathrm{H}$ NMR data (DMSO- $\left.d_{6}\right): \delta 2.72(\mathrm{~s}$, $\left.3 \mathrm{H}, \mathrm{Ar}-\mathrm{CH}_{3}\right), 7.24$ (s, 2H, $\left.-\mathrm{NH}_{2}\right), 7.61$ (s, $\left.1 \mathrm{H}, \mathrm{Ar}-\mathrm{H}\right)$, 8.01 (s, 1H, Ar-H) 8.77 (s, 1H, Ar-H); ${ }^{13} \mathrm{C}$ NMR data $\left(\mathrm{DMSO}-d_{6}\right): \delta 24.4,72.1,81.4,110.7,113.1,114.0$, $138.8,144.5,147.3,151.1,153.9,165.2 ; \mathrm{MS}(\mathrm{m} / \mathrm{z})$ : $265(\mathrm{M}+1,100 \%)$; Anal. Calcd. (\%) For $\mathrm{C}_{12} \mathrm{H}_{8} \mathrm{~N}_{8}$ (264.25): C, 54.54; H, 3.05; N, 42.41; Found (\%) C, $54.32 ; \mathrm{H}, 3.26 ; \mathrm{N}, 42.19$.

2.4f Synthesis of compounds 4 and ethyl 5-amino1H-pyrazole-4-carboxylate (10): A solution of ethyl 5-amino-1-(3-cyano-5-methylpyrazolo[1,5- $a$ ]pyrimidin7-yl)- $1 H$-pyrazole-4-carboxylate (6) $(0.311 \mathrm{~g}, 0.001 \mathrm{~mol})$ and ammonia $(0.100 \mathrm{~g}, 0.002 \mathrm{~mol})$ in tetrahydrofuron $(10 \mathrm{~mL})$ was stirred at $50-55^{\circ} \mathrm{C}$ for $5 \mathrm{~min}$. After completion of the reaction (TLC check with dichloromethane: methanol 9:1) obtained solid was suction filtered, washed with hexane, dried and it was a mixture of two compounds (TLC check). The mixture was separated by column eluting with $0.5 \%$ methanol in dichloromethane and was characterized by spectral and analytical data. Compound $\mathbf{4}$ is already in hand and its structure was confirmed by comparison of physical data. Compound 10: yield-0.33 g, $12 \%$; M.p. $102-103^{\circ} \mathrm{C}$, (Sigma-Aldrich CAS No. 103259-35-4). M.p. $101-104^{\circ} \mathrm{C}$., IR (KBr): 3588, 3320, 3260, 3031, 2983, 2219, 1709, $1610 \mathrm{~cm}^{-1}$; ${ }^{1} \mathrm{H}$ NMR data (DMSO- $\left.d_{6}\right): \delta 1.20(\mathrm{t}, J=7.2 \mathrm{~Hz}, 3 \mathrm{H}$, $\left.\mathrm{CH}_{3}\right), 4.11\left(\mathrm{q}, J=7.2 \mathrm{~Hz}, 2 \mathrm{H}, \mathrm{CH}_{2}\right), 5.81(\mathrm{~s}, 2 \mathrm{H}$, $-\mathrm{NH}_{2}$ ), 7.51 (s, 1H, Ar-H), 11.86 (bs, 1H, -NH).

2.4g Synthesis of compounds 2 and 10: A solution of ethyl 5-amino-1-(3-cyano-5-methylpyrazolo[1,5- $a$ ]pyrimidin-7-yl)- $1 H$-pyrazole-4-carboxylate (6) $(0.311 \mathrm{~g}$, $0.001 \mathrm{~mol})$ and hydrazine hydrate $(0.100 \mathrm{~g}, 0.002 \mathrm{~mol})$ in ethanol $(10 \mathrm{~mL})$ was stirred at $50-55^{\circ} \mathrm{C}$ for $5 \mathrm{~min}$. After completion of the reaction (TLC check with dichloromethane: methanol 9:1) obtained solid was suction 
filtered, washed with hexane, dried and it was a mixture of two compounds (as observed from TLC). The mixture was separated by column eluting with $0.5 \%$ methanol in dichloromethane and characterized by spectral and analytical data. The characterization data for $\mathbf{2}$ and $\mathbf{1 0}$ are given above.

2.4h Synthesis of (E)-Ethyl 1-(3-cyano-5-methylpyrazolo[1,5-a]pyrimidin-7-yl)-5(ethoxymethylene)amino)1H-pyrazole-4-carboxylate (12): To a solution of (6) $(0.311 \mathrm{~g}, 0.001 \mathrm{~mol})$, triethyl orthoformate $(0.296 \mathrm{~g}$, $0.002 \mathrm{~mol})$ in acetic anhydride $(10 \mathrm{~mL})$ was added and the reaction mixture was stirred at $110-115^{\circ} \mathrm{C}$ for $15 \mathrm{~min}$. After completion of the reaction (TLC check with dichloromethane/methanol 9:1), the excess of solvent was removed under reduced pressure, the solid obtained was suction filtered, washed with water, dried and recrystallized from ethanol to afford compound $\mathbf{1 2}$. Colorless solid, yield-0.348 g, 95\%; M.p. $310-312^{\circ} \mathrm{C}$., IR (KBr): 2950, 2227, 1704, $1629 \mathrm{~cm}^{-1} ;{ }^{1} \mathrm{H}$ NMR data $\left(\mathrm{DMSO}-d_{6}\right): \delta 1.00\left(\mathrm{t}, J=7.2 \mathrm{~Hz}, 3 \mathrm{H}, \mathrm{CH}_{3}\right), 1.25(\mathrm{t}$, $\left.J=7.2 \mathrm{~Hz}, 3 \mathrm{H}, \mathrm{CH}_{3}\right), 2.72\left(\mathrm{~s}, 3 \mathrm{H}, \mathrm{Ar}-\mathrm{CH}_{3}\right), 3.95(\mathrm{q}, J=$ $\left.7.8 \mathrm{~Hz}, 2 \mathrm{H}, \mathrm{CH}_{2}\right), 4.20$ (q, $\left.J=7.8 \mathrm{~Hz}, 2 \mathrm{H}, \mathrm{CH}_{2}\right), 7.6$ (s, $1 \mathrm{H}, \mathrm{Ar}-\mathrm{H}), 8.12(\mathrm{~s}, 1 \mathrm{H}, \mathrm{Ar}-\mathrm{H}), 8.47(\mathrm{~s}, 1 \mathrm{H},-\mathrm{N}=\mathrm{CH})$ $8.72(\mathrm{~s}, 1 \mathrm{H}, \mathrm{Ar}-\mathrm{H}) ;{ }^{13} \mathrm{C}$ NMR data $\left(\mathrm{DMSO}-d_{6}\right): \delta$ 13.4, 13.9, 24.5, 59.9, 63.3, 81.4, 102.7, 110.1, 112.9, 139.2, 144.3, 147.3, 150.7, 151.6, 161.8, 164.1, 165.3; MS (m/z:) $368(\mathrm{M}+1,100 \%)$; Anal.Calcd. (\%) For $\mathrm{C}_{17} \mathrm{H}_{17} \mathrm{~N}_{7}$ (367.36): C, 55.58; H, 4.66; N, 26.69; Found (\%) C, 55.35; H, 4.39; N, 26.41.

2.4i Synthesis of compounds (13a-b) and (6): A mixture of compound $12(0.367 \mathrm{~g}, 0.001 \mathrm{~mol})$ and primary amine $(0.002 \mathrm{~mol})$ in anhydrous acetonitrile $(10 \mathrm{~mL})$ was stirred at $40^{\circ} \mathrm{C}$ for $8-24 \mathrm{~h}$. After completion of the reaction (TLC check with dichloromethane/methanol 9:1), the solvent was removed under reduced pressure to obtain solid. It was suction filtered, washed with cold acetonitrile, dried and purified by column chromatography (eluting with $1 \%$ methanol in dichloromethane) to afford compound $\mathbf{1 3} \mathbf{a}-\mathbf{b}$ and $\mathbf{6}$.

7-(4,5-Dihydro-4-oxo-5-phenylpyrazolo[3,4-d]pyrimidin-1-yl)-5-methylpyrazolo[1,5-a] pyrimidine-3-carbonitrile (13a): IR (KBr): 3008, 2904, 2227, 1665, $1600 \mathrm{~cm}^{-1}$; Colorless solid, yield $0.184 \mathrm{~g}, 50 \%$; M.p. $339-341{ }^{\circ} \mathrm{C} ;{ }^{1} \mathrm{H}$ NMR data (DMSO- $d_{6}$ ): $\delta 2.65$ (s, $\left.3 \mathrm{H}, \mathrm{Ar}-\mathrm{CH}_{3}\right), 6.52$ (s, 1H, Ar-H), 7.42-7.62 (m, 6H, Ar$\mathrm{H}), 8.72(\mathrm{~s}, 1 \mathrm{H}, \mathrm{Ar}-\mathrm{H}), 10.44(\mathrm{~s}, 1 \mathrm{H}, \mathrm{Ar}-\mathrm{H}) ;{ }^{13} \mathrm{C}$ NMR data $\left(\mathrm{DMSO}-d_{6}\right): \delta 24.6,81.7,102.9,111.1,113.2$, 122.4, 122.4, 125.2, 131.1, 131.1, 133.4, 139.5, 144.8, $147.9,151.1,162.3,163.8,165.7,166.2 ; \mathrm{MS}(\mathrm{m} / \mathrm{z})$ : $369(\mathrm{M}+1,100 \%)$; Anal. Calcd. (\%) For $\mathrm{C}_{19} \mathrm{H}_{12} \mathrm{~N}_{8} \mathrm{O}$
(368.35): C, 61.95; H, 3.28; N, 30.42; Found (\%) C, 61.68; H, 2.98.; N, 30.68.

7-(5-(4-Chlorophenyl)-4,5-dihydro-4-oxopyrazolo[3,4d]pyrimidin-1-yl)-5-methylpyrazolo [1,5-a]pyrimidine3-carbonitrile (13b): IR (KBr): 3012, 2907, 2233, 1663, $1600 \mathrm{~cm}^{-1}$; Colorless solid, yield $0.201 \mathrm{~g}, 50 \%$; M.p. $351-353^{\circ} \mathrm{C} ;{ }^{1} \mathrm{H}$ NMR data $\left(\mathrm{DMSO}-d_{6}\right): \delta 2.69$ (s, 3H, Ar- $\left.\mathrm{CH}_{3}\right), 6.53$ (s, 1H, Ar-H), 7.52-7.73 (m, 5H, $\mathrm{Ar}-\mathrm{H}), 8.73$ (s, 1H, Ar-H), 10.49 (s, 1H, Ar-H); ${ }^{13} \mathrm{C} \mathrm{NMR}$ data $\left(\mathrm{DMSO}-d_{6}\right): \delta 25.0,81.5,103.0,111.4,113.3$, 123.0, 123.0, 132.0, 132.0, 133.1, 133.6, 140.1, 145.2, $148.1,151.7,162.6,164.0,165.6,166.3 ; \mathrm{MS}(\mathrm{m} / \mathrm{z})$ : $402\left(\mathrm{M}^{+}, 100 \%\right), 404(\mathrm{M}+2,33 \%)$; Anal. Calcd. (\%) For $\mathrm{C}_{19} \mathrm{H}_{11} \mathrm{ClN}_{8} \mathrm{O}$ (402.8): C, 56.65; $\mathrm{H}, 2.75 ; \mathrm{N}, 27.82$; Found (\%) C, 56.41; H, 2.98.; N, 28.02.

2.4j Synthesis of compounds $(\mathbf{1 4} \boldsymbol{a}-\boldsymbol{d})$ : A mixture of compound $2(0.188 \mathrm{~g}, 0.001 \mathrm{~mol})$ and the corresponding anhydrides $(0.001 \mathrm{~mol})$ in DES (Choline chloride: urea) $(1 \mathrm{gm})$ and catalytic amount of glacial acetic acid ( 2 drops) was stirred at $50^{\circ} \mathrm{C}$ for 5-8 h. After completion of the reaction (TLC check with dichloromethane/ methanol 9:1) the viscous mass was cooled and extracted with a mixture of hexane/ethyl acetate (1:4) four times $(4 \times 10 \mathrm{~mL})$. The organic layer was then washed with brine solution, water and dried over anhydrous sodium sulfate. Then, solvent was removed under reduced pressure to obtain solid which was purified by column chromatography (eluting with 5\% methanol in dichloromethane) to furnish $\mathbf{1 4 a - d}$.

7-(2,5-Dioxopyrrolidin-1-ylamino)-5-methylpyrazolo [1, 5-a]pyrimidine-3-carbonitrile (14a): IR (KBr): 3205, 3030, 2229, 1670, 1612, $1571 \mathrm{~cm}^{-1} ;{ }^{1} \mathrm{H}$ NMR data $\left(\mathrm{CDCl}_{3}\right): \delta 2.08\left(\mathrm{~s}, 3 \mathrm{H}, \mathrm{Ar}-\mathrm{CH}_{3}\right), 2.62(\mathrm{~s}, 4 \mathrm{H}$, pyrrolidone), $6.76(\mathrm{~s}, 1 \mathrm{H}, \mathrm{Ar}-\mathrm{H}), 8.20(\mathrm{~s}, 1 \mathrm{H}, \mathrm{Ar}-\mathrm{H}), 8.84$ (bs, $1 \mathrm{H},-\mathrm{NH}) ;{ }^{13} \mathrm{C}$ NMRdata (DMSO- $\left.d_{6}\right): \delta 24.2,31.0$ (2C's), 77.3, 88.6, 114.5, 146.5, 149.5, 150.7, 162.3, 167.3 (2C's); MS (m/z): $271(\mathrm{M}+1,100 \%)$; Anal. Calcd. (\%) For $\mathrm{C}_{12} \mathrm{H}_{10} \mathrm{~N}_{6} \mathrm{O}_{2}$ (270.25): $\mathrm{C}, 53.33 ; \mathrm{H}$, $3.73 ; \mathrm{N}, 31.10$. Found (\%) C, 53.10; H, 3.45; N, 30.82 .

7-(2,5-Dioxo-2H-pyrrol-1(5H)-ylamino)-5-methylpyrazolo[1,5-a]pyrimidine-3-carbonitrile (14b): $\quad \mathrm{IR}(\mathrm{KBr})$ : 3231, 3065, 2221, 1680, 1625, $\mathrm{cm}^{-1}$; ${ }^{1} \mathrm{H}$ NMR data $\left(\mathrm{CDCl}_{3}\right): \delta 2.10\left(\mathrm{~s}, 3 \mathrm{H}, \mathrm{Ar}-\mathrm{CH}_{3}\right), 4.32(\mathrm{~s}, 2 \mathrm{H}$, pyrrolidone), 6.79 (s, 1H, Ar-H), 8.25 (s, 1H, Ar-H), 8.87 (bs, $1 \mathrm{H},-\mathrm{NH})$; MS (m/z): 269 (M+1, 100\%); Anal. Calcd. (\%) For $\mathrm{C}_{12} \mathrm{H}_{8} \mathrm{~N}_{6} \mathrm{O}_{2}$ (268.23): C, 53.73; H, 3.01; N, 31.33. Found (\%) C, 53.46; H, 3.18; N, 31.49.

7-(1,3-Dioxoisoindolin-2-ylamino)-5-methylpyrazolo[1, 5-a]pyrimidine-3-carbonitrile 14c: Colorless solid; 
yield-0.270 g, 85\%; M.p. $296-297^{\circ} \mathrm{C}$; IR (KBr): 3225 , 2915, 2227, 1693, $1618 \mathrm{~cm}^{-1}$; ${ }^{1} \mathrm{H}$ NMR data (DMSO$\left.d_{6}\right): \delta 2.12\left(\mathrm{~s}, 3 \mathrm{H}, \mathrm{Ar}-\mathrm{CH}_{3}\right), 6.71(\mathrm{~s}, 1 \mathrm{H}, \mathrm{Ar}-\mathrm{H}), 7.5-7.9$ (m, 4H, Ar-H), 8.69 (s, 1H, Ar-H), 10.89 (bs, 1H, -NH); ${ }^{13} \mathrm{C}$ NMR data (DMSO- $\left.d_{6}\right): \delta 24.5,78.1,88.5,114.7$, 128.4 (2C's), 133.4 (2C's), 134.0 (2C's), 147.1, 149.2, 151.9, 162.5, 166.5 (2C's); MS $(\mathrm{m} / \mathrm{z}): 319(\mathrm{M}+1$, $100 \%$ ); Anal.Calcd. (\%) For $\mathrm{C}_{16} \mathrm{H}_{10} \mathrm{~N}_{6} \mathrm{O}_{2}$ (318.29): C, 60.38 ; H, 3.17; N, 26.40. Found (\%): C, 60.75; H, 3.49; N, 26.73.

7-(Hexahydro-1, 3-dioxo-1H-isoindol-2(3H)-ylamino)5-methylpyrazolo[1, 5-a] pyrimidine-3-carbonitrile $(\mathbf{1 4 d})$ : IR (KBr): 3230, 2923, 2221, 1710, 1627, 1560, 1537 $\mathrm{cm}^{-1} ;{ }^{1} \mathrm{H}$ NMR data (DMSO- $\left.d_{6}\right): \delta 1.77\left(\mathrm{~s}, 4 \mathrm{H},-\mathrm{CH}_{2}\right)$, $2.37\left(\mathrm{~s}, 4 \mathrm{H},-\mathrm{CH}_{2}\right), 2.20\left(\mathrm{~s}, 3 \mathrm{H}, \mathrm{Ar}-\mathrm{CH}_{3}\right), 2.52$ (s, $2 \times$ $\mathrm{CH}), 6.69$ (s, 1H, Ar-H), 8.78 (s, 1H, Ar-H), 10.79 (bs, $1 \mathrm{H},-\mathrm{NH}) ;{ }^{13} \mathrm{C}$ NMR data (DMSO- $d_{6}$ ): $\delta 24.3$, 25.5 (2C's), 27.1 (2C's), 42.1 (2C's), 78.8, 88.8, 115.7, 147.1, 150.1, 152.1, 163.2, 170.1 (2C's); MS ( $\mathrm{m} / \mathrm{z})$ : $324\left(\mathrm{M}^{+}, 100 \%\right)$; Anal. Calcd. (\%) For $\mathrm{C}_{16} \mathrm{H}_{16} \mathrm{~N}_{6} \mathrm{O}_{2}$ (324.34): C, 59.25; H, 4.97; N, 25.91. Found (\%) C, $58.98 ; \mathrm{H}, 4.81 ; \mathrm{N}, 25.70$.

2.4k Synthesis of compound 16 and 17: General procedure for the synthesis of compounds $\mathbf{1 6}$ and 17: A mixture of compound $3(0.173 \mathrm{~g}, 0.001 \mathrm{~mol})$ and $\alpha$-acetyl- $\gamma$-butyrolactone $15(0.128 \mathrm{~g}, 0.001 \mathrm{~mol})$ in dry toluene: phosphorous oxychloride (3:7) was heated under reflux for $12 \mathrm{~h}$. After completion of reaction (TLC check with dichloromethane/methanol 9:1), excess of solvent was removed under reduced pressure and poured in ice cold water $(20 \mathrm{~mL})$, stirred, suction filtered to afford mixture of two compounds, which were separated by column chromatography (eluting with $0.5 \%$ ethyl acetate in hexane) to furnish $\mathbf{1 6}$ and $\mathbf{1 7}$.

6-Chloro-7-(2-chloroethyl)-5,8-dimethylpyrazolo[1,5a]pyrido[3,2-e]pyrimidine-3-carbonitrile (16): Colorless solid; yield-0.153 g, 48\%; M.p. $251-253^{\circ} \mathrm{C}$, IR (KBr): 3050, 2938, 2227, $1615 \mathrm{~cm}^{1} ;{ }^{1} \mathrm{H}$ NMR data $\left(\mathrm{CDCl}_{3}\right): \delta 2.45\left(\mathrm{~s}, 3 \mathrm{H}, \mathrm{Ar}-\mathrm{CH}_{3}\right), 2.71\left(\mathrm{~s}, 3 \mathrm{H}, \mathrm{Ar}-\mathrm{CH}_{3}\right)$,

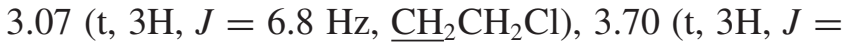
$\left.6.8 \mathrm{~Hz}, \mathrm{CH}_{2} \mathrm{CH}_{2} \mathrm{Cl}\right), 8.27$ (s, $\left.1 \mathrm{H}, \mathrm{Ar}-\mathrm{H}\right) ;{ }^{13} \mathrm{C} \mathrm{NMR}$ data $\left(\right.$ DMSO- $\left.d_{6}\right): \delta 22.1,24.1,32.2,38.2,77.3,90.6,114.5$,
$142.8,146.4,148.3,152.7,159.9,162.0,168 ; \mathrm{MS}$ $(\mathrm{m} / \mathrm{z}): 319\left(\mathrm{M}^{+}, 100 \%\right) 321(\mathrm{M}+2,65.2 \%) 323(\mathrm{M}+4$, 10.5\%); Anal. Calcd. (\%) For $\mathrm{C}_{14} \mathrm{H}_{11} \mathrm{Cl}_{2} \mathrm{~N}_{5}$ (320.18): C, 52.52; H, 3.46; N, 21.87. Found (\%): C, 52.67; H, $3.80 ; \mathrm{N}, 21.62$.

6,10-Dimethyl-7,8-dihydrofuro[2',3':4,5]pyrido[3,2-e] pyrazolo[1,5-a]pyrimidine-1-carbonitrile (17): Colorless solid; yield-0.153 g, 48\%; M.p. $250-253^{\circ} \mathrm{C}$, IR (KBr): 3043, 2910, 2232, 1617, $1205 \mathrm{~cm}^{-1} ;{ }^{1} \mathrm{H}$ NMR data $\left(\mathrm{CDCl}_{3}\right): \delta 2.45\left(\mathrm{~s}, 3 \mathrm{H}, \mathrm{Ar}-\mathrm{CH}_{3}\right), 2.71(\mathrm{~s}, 3 \mathrm{H}$, $\mathrm{Ar}-\mathrm{CH}_{3}$ ), 2.94 (t, $3 \mathrm{H}, J=6.3 \mathrm{~Hz}, \mathrm{CH}_{2} \mathrm{CH}_{2} \mathrm{O}$ ), 3.81 (t, $\left.3 \mathrm{H}, J=6.3 \mathrm{~Hz}, \mathrm{CH}_{2} \mathrm{CH}_{2} \mathrm{O}\right), 8.27(\mathrm{~s}, 1 \mathrm{H}, \mathrm{Ar}-\mathrm{H})$; ${ }^{13} \mathrm{C}$ NMR (DMSO- $\left.d_{6}\right): \delta 22.5,24.2,26.5,76.4,77.3$, $90.4,114.5,146.2,146.3,148.5,152.4,162.1,166.8$, 168.4; MS (m/z): $265\left(\mathrm{M}^{+}, 100 \%\right)$; Anal. Calcd. (\%) For $\mathrm{C}_{14} \mathrm{H}_{11} \mathrm{~N}_{5} \mathrm{O}$ (265.27): C, 63.39; H, 4.18; N, 26.40. Found (\%): C, 63.67; H, 3.89; N, 26.82.

\section{Results and discussion}

\subsection{Chemistry}

As part of our ongoing investigations, herein we directed our attention towards the development of new and efficient methods for synthesis of pyrazolo[1,5- $a$ ]pyrimidine derivatives using 7-chloro-5-methylpyrazolo[1, 5-a ]pyrimidine-3-carbonitrile $\mathbf{1}$ as a substrate. ${ }^{29} \mathrm{Com}$ pound 1 was synthesized by the known literature procedure. ${ }^{23}$ The reaction sequence employed for synthesis of two key scaffolds, 7-hydrazinyl-5-methylpyrazolo[1, 5- $a$ ] pyrimidine-3-carbonitrile 2 and 7-amino-5-methylpyrazolo[1,5- $a$ ] pyrimidine-3-carbonitrile $\mathbf{4}$ is given in Scheme 1.

The reaction of compound $\mathbf{1}$ with hydrazine hydrate in ethanol at room temperature underwent $\mathrm{S}_{N} \mathrm{Ar}$ displacement to give hydrazine derivative $\mathbf{2}$ in $92 \%$ yield. It was characterised by spectroscopic and analytical data. For instance, the ${ }^{1} \mathrm{H}$ NMR showed broad singlet at $\delta 4.82$ and 9.56 which verified $-\mathrm{NH}_{2}$ and $-\mathrm{NH}$ protons, respectively. While the IR spectrum showed strong absorption bands at 3591, 3321, 3267 and $2219 \mathrm{~cm}^{-1}$ which indicated presence of $-\mathrm{NH}_{2},-\mathrm{NH}$ and $-\mathrm{CN}$, respectively. The MS showed a molecular ion peak at $m / z=189[\mathrm{M}+1]$ corresponding to the molecular

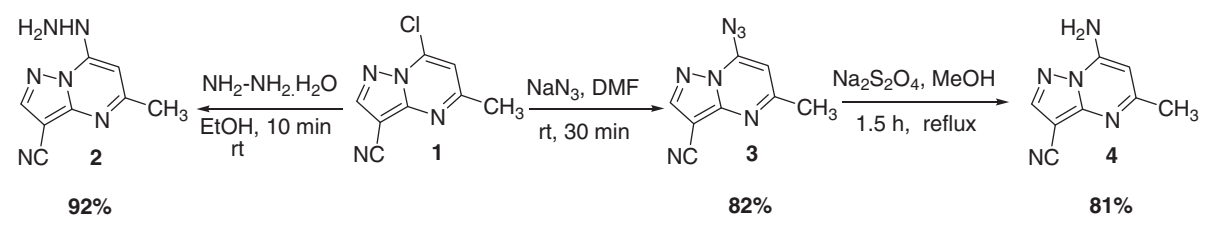

Scheme 1. Synthesis of 7-hydrazinyl-5-methylpyrazolo[1,5-a]pyrimidine-3-carbonitrile 2 and 7-amino-5-methylpyrazolo[1,5-a] pyrimidine-3-carbonitrile 4. 
formula $\mathrm{C}_{8} \mathrm{H}_{8} \mathrm{~N}_{6}$. The azidation of $\mathbf{1}$ was successfully achieved by the $S_{N}$ Ar displacement of chloro by azide using sodium azide in dimethyl formamide to obtained compound $\mathbf{3}$ in $82 \%$ yield. The structure of $\mathbf{3}$ was confirmed by spectral and analytical data. The characteristic stretching frequency was observed at $2150 \mathrm{~cm}^{-1}$ due to azide group in IR spectrum of $\mathbf{3}$. It is worth to note that addition of sodium azide in one lot into reaction mixture at $0^{\circ} \mathrm{C}$ or at higher temperature turned the reaction mixture to green color and that might lead to decomposition of product; hence, sodium azide was added portion wise at $0-5^{\circ} \mathrm{C}$ under stirring. The reduction of azido group was successfully achieved by using sodium dithionite in methanol at $65^{\circ} \mathrm{C}$ to obtain the desired compound $\mathbf{4}$ in $81 \%$ yield. The structure of compound $\mathbf{4}$ was confirmed by spectroscopic and analytical data. The ${ }^{1} \mathrm{H}$ NMR showed four broad singlets at $\delta 2.40,6.18,8.14$ and 8.55 corresponding to $-\mathrm{CH}_{3}$, pyrimidine ring protons, $-\mathrm{NH}_{2}$ and pyrazole ring protons, respectively. In IR spectrum bands at 3337 and $3332 \mathrm{~cm}^{-1}$ correspond to $-\mathrm{NH}_{2}$ group (Scheme 2).

Further the treatment of compound 2 with ethoxymethylenecyanoacetate $\mathbf{5}$ in presence of ethanol underwent annulation of pyrazole ring to afford ethyl 5-amino-1-(3-cyano-5-methylpyrazolo[1,5-a]pyrimidin7-yl)- $1 H$-pyrazole-4-carboxylate $\mathbf{6}$, which was characterized by spectroscopic methods. For instance, the ${ }^{1} \mathrm{H}$ NMR spectrum of compound $\mathbf{6}$ showed triplet-quartet pattern at $\delta 1.35$ and 4.32 representing the protons of ethoxy group, while $-\mathrm{NH}_{2}$ protons appeared as broad singlet at $\delta 6.66$ and the MS showed a molecular ion peak at $\mathrm{m} / \mathrm{z}=312[\mathrm{M}+1]$ corresponding to the molecular formula $\mathrm{C}_{14} \mathrm{H}_{13} \mathrm{~N}_{7}$. Similarly, condensation of compound 2 with ethoxymethylenmalononitrile 7 afforded compound $\mathbf{8}$ in $94 \%$ yield. Compound $\mathbf{8}$ was characterized by spectroscopic and analytical data. The presence of two nitrile functionalities were confirmed by appearance of bands at 2237 and $2219 \mathrm{~cm}^{-1}$ in its IR spectrum, which were in corroboration with the signals at $\delta 72.1$ and 81.4 in its ${ }^{13} \mathrm{C}$ NMR.
An attempt to convert the ester functionality $\mathbf{6}$ into amide with ammonia was unsuccessful. Thus, compound 6 on treatment with ammonia in THF at 50$55^{\circ} \mathrm{C}$ yielded a mixture of two compounds $\mathbf{A}$ and $\mathbf{B}$ with $63 \%$ and $12 \%$, respectively (Scheme 3 ). This mixture was separated by column chromatography eluting with $0.5 \%$ methanol in dichloromethane. Compound $\mathbf{A}$ was assigned to structure $\mathbf{4}$ while compound $\mathbf{B}$ was
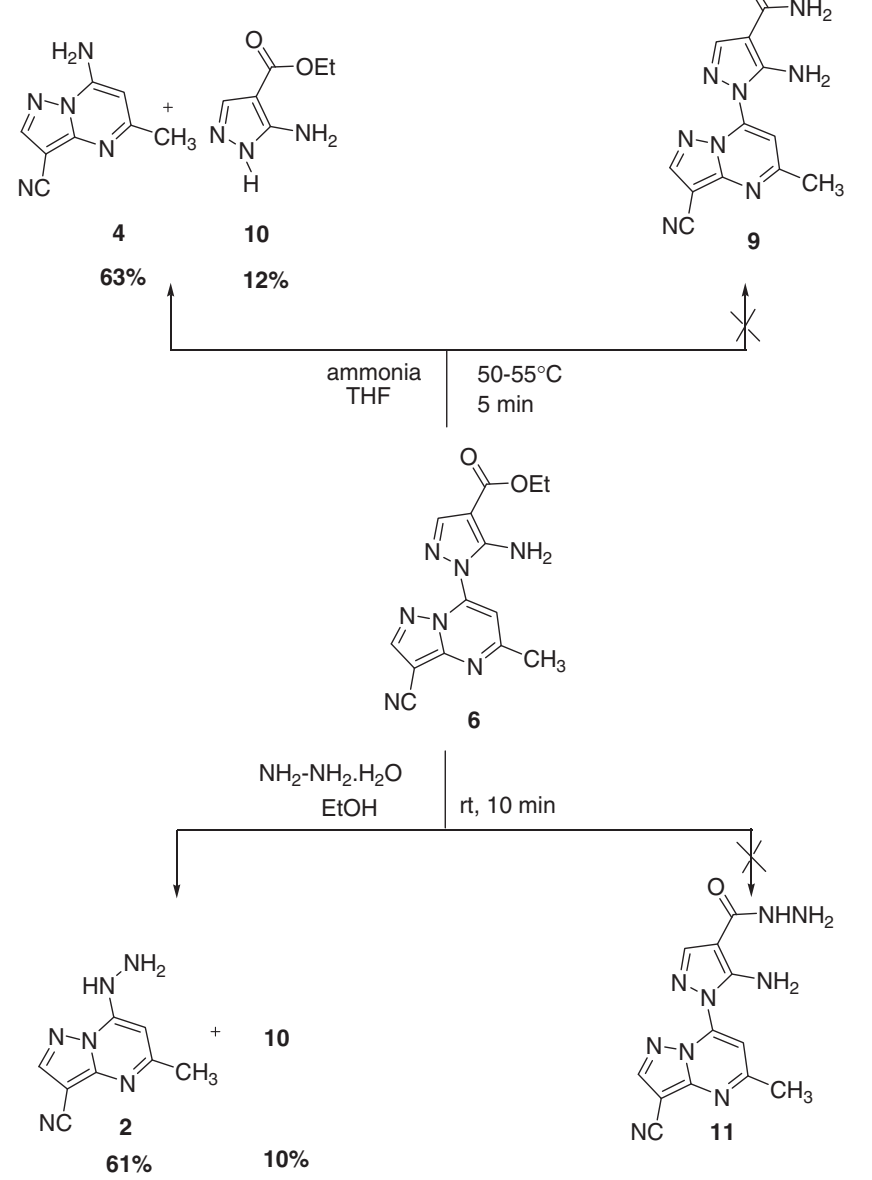

Scheme 3. Reaction on ethyl 5-amino-1-(3-cyano-5-methylpyrazolo $[1,5-a]$ pyrimidin-7-yl)- $1 H$-pyrazole-4-carboxylate.
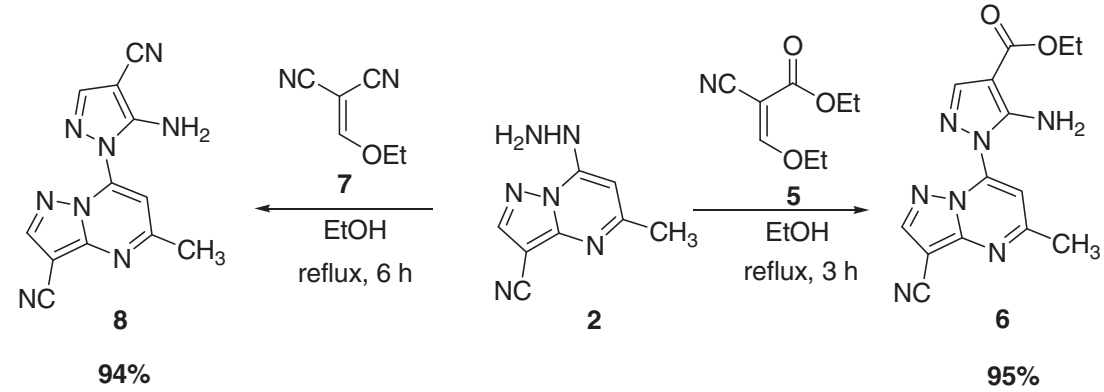

Scheme 2. Synthesis of Ethyl 5-amino-1-(3-cyano-5-methylpyrazolo[1,5- $a$ ] pyrimidin-7-yl)- $1 \mathrm{H}$-pyrazole-4-carboxylate 6 and 7-(5-Amino-4-cyano- $1 \mathrm{H}-$ pyrazol-1-yl)-5-methylpyrazolo[1,5-a]pyrimidine-3-carbonitrile $\mathbf{8}$. 
assigned to structure $\mathbf{1 0}$ on the basis of spectroscopic and analytical data. In this reaction, expected amide 9 was not formed, however, the heterocyclic nitrogen bond between pyrazolo pyrimidine and pyrazole ring was broken which could be due to basic medium. Similarly, we intended to convert ester group in $\mathbf{6}$ into acid hydrazide 11 which was also unsuccessful in an analogous manner; the carbon-nitrogen bond fission was observed and mixture of compounds $\mathbf{2}$ and $\mathbf{1 0}$ was obtained in $61 \%$ and $10 \%$ yield, respectively, which were separated by column chromatography and characterized by spectroscopic and analytical data.

The amino functionality in compound $\mathbf{6}$ could be utilized for the annulations of pyrimidine on pyrazole nucleus. Thus, $\mathbf{6}$ was treated with triethyl orthoformate using acetic anhydride as a catalyst which yielded synthon 12 in $90 \%$ yield (Scheme 4).

Further compound $\mathbf{1 2}$ reacted with aniline and substituted anilines yielded a mixture of two compounds $\mathbf{A}$ and $\mathbf{B}$. The mixture was separated by column chromatography eluting with $1 \%$ methanol in dichloromethane. On the basis of spectroscopic and analytical data, compound 13a was assigned to $\mathbf{A}$ and compound $\mathbf{6}$ was assigned to $\mathbf{B}$. Analogously, compound $\mathbf{1 2}$ with $p$-chloro aniline yielded a mixture of two compounds, 13b and 6, which were characterised by spectral and analytical data.

The reactive hydrazine functionality in $\mathbf{2}$ was readily converted to their dioxopyrrolidinyl $(\mathbf{1 4 a}-\mathbf{b})$ and dioxoisoindolyl (14c-d) derivatives with anhydrides (Scheme 5). Herein, we studied the different catalyst, reaction condition and solvent on model reaction (Table 2). The result revealed that when the reaction was carried out at $100^{\circ} \mathrm{C}$ in presence of acetic acid, products in good yield were obtained even after prolonged reaction time. However, analogous reaction in DES (ChCl:glycerol) and catalytic amount of acetic acid at $50^{\circ} \mathrm{C}$ furnished desired compounds with increased yield and reduced reaction time. Other eutectic mixtures (cholin chloride:urea and cholin chloride:malonic acid) were also tried to improve the yields. The DES of (cholin chloride:urea) in presence of catalytic amount of acetic acid was found to be most effective amongst the tested ones. It was also noted that, analogous reaction in the absence of acetic acid did not give satisfactory results. The structural assignments $\mathbf{1 4 a}-\mathbf{d}$ is based upon spectroscopic and analytical data (given in Experimental section).

Compound 4 having amino functionality was further employed for the annulation of tricyclic and tetracyclic heterocycles by condensation reaction with $\alpha$-acetyl- $\gamma$-butyrolactone $\mathbf{1 5}$. Thus, the condensation reaction of compound 4 with $\alpha$-acetyl- $\gamma$-butyrolactone in phosphorous oxychloride/toluene (7:3) underwent cyclocondensation reaction to afford a mixture of
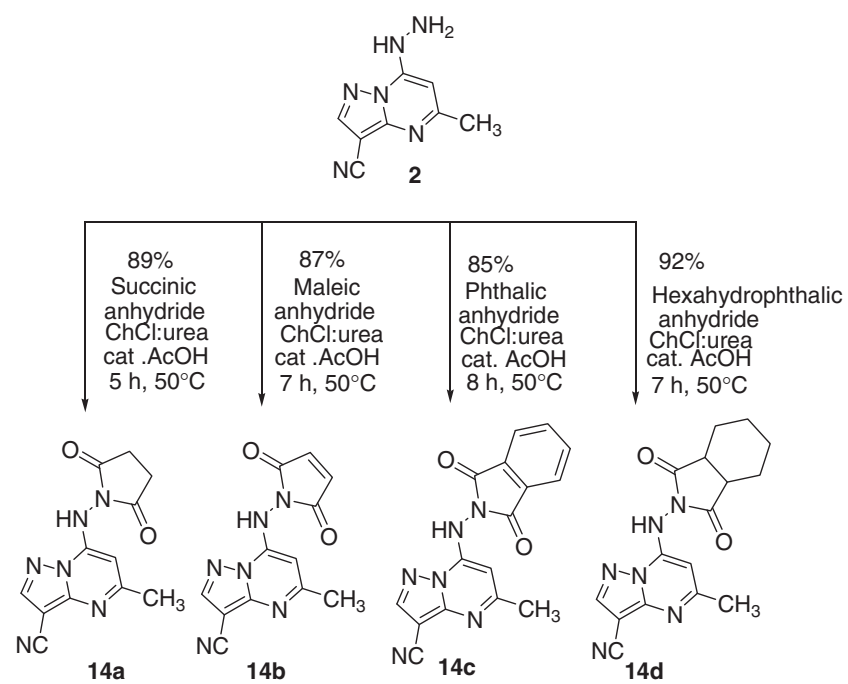

Scheme 5. Synthesis of dioxo pyrrolidones and dioxoisoindol 14 a-d.

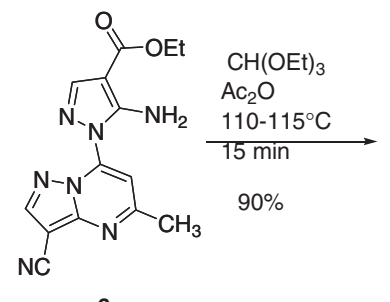

6

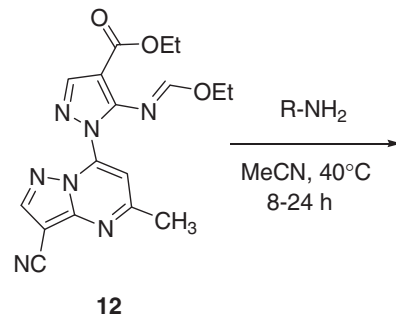

12
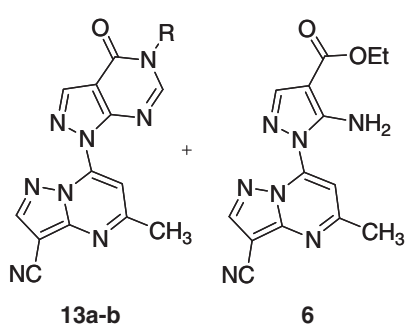

\begin{tabular}{l|l}
13 & $\mathrm{R}$ \\
\hline $\mathrm{a}$ & $-\mathrm{C}_{6} \mathrm{H}_{5}$ \\
$\mathrm{~b}$ & $p-\mathrm{CH}_{3} \mathrm{C}_{6} \mathrm{H}_{4}$
\end{tabular}

Scheme 4. Synthesis of pyrazolo[3,4- $d]$ pyrimidines- pyrazolo[1,5- $a$ pyrimidine 13a-b. 
Table 2. Optimization of solvent and catalysts for the synthesis of dioxo pyrrolidones and dioxoisoindol $\mathbf{1 4}$ a-d.

\begin{tabular}{|c|c|c|c|c|c|}
\hline Entry & Comp. No & Solvent, catalyst & Time(h) & Temp $\left({ }^{\circ} \mathrm{C}\right)$ & Yield $^{\mathrm{a}}(\%)$ \\
\hline \multirow[t]{4}{*}{1} & $14 \mathbf{a}$ & $\mathrm{AcOH}$ & 12 & 100 & 58 \\
\hline & & DES(ChCl:glycerol), AcOH & 6 & 50 & 60 \\
\hline & & DES(ChCl:urea), AcOH & 5 & 50 & 89 \\
\hline & & DES(ChCl:malonic acid), AcOH & 5.5 & 50 & 97 \\
\hline \multirow[t]{4}{*}{2} & 14b & $\mathrm{AcOH}$ & 15 & 100 & 55 \\
\hline & & $\mathrm{DES}(\mathrm{ChCl}$ :glycerol), $\mathrm{AcOH}$ & 8 & 50 & 62 \\
\hline & & DES(ChCl:urea), AcOH & 7 & 50 & 87 \\
\hline & & DES(ChCl:malonic acid), $\mathrm{AcOH}$ & 7 & 50 & 86 \\
\hline \multirow[t]{4}{*}{3} & $14 \mathrm{c}$ & $\mathrm{AcOH}$ & 13 & 100 & 54 \\
\hline & & DES(ChCl:glycerol), AcOH & 9 & 50 & 70 \\
\hline & & DES(ChCl:urea), AcOH & 8 & 50 & 85 \\
\hline & & DES(ChCl:malonic acid), $\mathrm{AcOH}$ & 8.5 & 50 & 82 \\
\hline \multirow[t]{4}{*}{4} & 14d & $\mathrm{AcOH}$ & 13 & 100 & 57 \\
\hline & & DES(ChCl:glycerol), AcOH & 8 & 50 & 68 \\
\hline & & DES(ChCl:urea), AcOH & 7 & 50 & 92 \\
\hline & & DES(ChCl:malonic acid), $\mathrm{AcOH}$ & 8 & 50 & 91 \\
\hline
\end{tabular}

6-chloro-7-(2-chloroethyl)-5,8-dimethylpyrazolo[1,5- $a]$ pyrido[3,2-e]pyrimidine-3-carbonitrile 16 and 6,10-dimethyl-7,8-dihydrofuro[ $\left[2^{\prime}, 3^{\prime}: 4,5\right]$ pyrido[3,2-e]pyrazolo [1,5-a]pyrimidine-1-carbonitrile $\mathbf{1 7}$ in $48 \%$ and $15 \%$ yield, respectively. The mixture was separated by column eluting with $0.5 \%$ methanol in chloroform. The structures of compounds $\mathbf{1 6}$ and $\mathbf{1 7}$ were confirmed by spectroscopic and analytical data.

\subsection{Biological activity}

The antimicrobial activities of the synthesized compounds were evaluated by the agar cup plate method. The antibacterial and antifungal assays were performed in Muller-Hinton broth and Czapek Dox broth, respectively. Evaluation was performed using the bacteria reseeded in broth for $24 \mathrm{~h}$ at $37^{\circ} \mathrm{C}$, and the fungi were reseeded in broth for $48 \mathrm{~h}$ at $25^{\circ} \mathrm{C}$. The antibacterial activity of tested samples was studied against one Gram positive Bacillus subtilis NCIM 2250 and Gram negative Escherichia Coli ATCC 25922 bacteria while Candida albicans MTCC 277, Candida tropicalis MTCC 184, Aspergillus niger MCIM 545 and Aspergillus clavatus MTCC 1323 were used as standard fungal strains. The compounds were diluted in DMF with required concentration for bioassay. DMF was also loaded as control. Streptomycin and griseofluvin were used as standards to evaluate the potency of the tested compounds under same conditions. The zone of inhibition was determined from the diameter of the zone of inhibition using caliper. Each inhibition zone was measured three times to get average value. The minimum inhibitory concentration (MIC) values were determined on $\mathrm{MH}$ agar plates by pouring the molten agar in Petri
Table 3. Antibacterial activity of compounds 6, 8, 13a-c, 14a-d, 16 and 17.

\begin{tabular}{lcc}
\hline Entry & $\begin{array}{c}\text { Bacillus subtilis } \\
\text { NCIM 2250 }\end{array}$ & $\begin{array}{c}\text { Escherichia Coli } \\
\text { ATCC 25922 }\end{array}$ \\
\hline $\mathbf{6}$ & ZI $^{\mathrm{a}}(\mathrm{MIC})^{\mathrm{b}}$ & $\mathrm{ZI}(\mathrm{MIC})$ \\
$\mathbf{8}$ & $17.1(25)$ & $15.4(20)$ \\
$\mathbf{1 3 a}$ & $16.1(20)$ & $14.2(25)$ \\
$\mathbf{1 3 b}$ & $14.3(15)$ & $13.1(20)$ \\
$\mathbf{1 3 c}$ & $\mathbf{1 4 . 0}(\mathbf{1 5})$ & $\mathbf{1 2 . 2 ( 1 0 )}$ \\
$\mathbf{1 4 a}$ & $14.2(20)$ & $16.3(25)$ \\
$\mathbf{1 4 b}$ & $\mathbf{1 5 . 2 ( 1 0 )}$ & $\mathbf{1 4 . 8}(\mathbf{1 0})$ \\
$\mathbf{1 4 c}$ & $17.0(20)$ & $16.4(20)$ \\
$\mathbf{1 4 d}$ & $15.1(25)$ & $16.2(25)$ \\
$\mathbf{1 6}$ & $\mathbf{1 6 . 4 ( 1 0 )}$ & $13.2(25)$ \\
$\mathbf{1 7}$ & $15.1(20)$ & $15.3(25)$ \\
Strept. & $14.1(25)$ & $\mathbf{1 6 . 4}(\mathbf{1 0})$ \\
\hline
\end{tabular}

Bold values indicate better results. ${ }^{\text {a }}$ Zone of inhibition in $\mathrm{mm}$. ${ }^{\mathrm{b}}$ Minimum inhibitory concentration in $\mu \mathrm{g} / \mathrm{mL}$.

${ }^{c}$ n.t. not tested.

dishes according to National Committee for Clinical Laboratory Standards (NCCLS, M7-A5 January 2000), containing the following concentrations $(\mathrm{mg} / \mathrm{mL})$ : 0 (control), 5, 10, 15, 20, 30, 40. The MIC was defined as the lowest concentration of tested samples showing no visible bacterial growth after $24 \mathrm{~h}$ incubation period at $37^{\circ} \mathrm{C}$.

The antibacterial and antifungal assay of compounds 6, 8, 13a-c, 14a-d, 16 and 17 are given in Tables 3 and 4 , respectively. The results depicted revealed that most of the tested compounds displayed variable inhibitory effects on the growth of the tested Gram positive and Gram negative bacterial strains, and also against antifungal strains in micromolar concentration. 
Table 4. Antifungal activity of compounds 6, 8, 13a-c, 14a-d, 16 and 17 .

\begin{tabular}{lcccc}
\hline Entry & $\begin{array}{c}\text { Candida albicans } \\
\text { MTCC 277 }\end{array}$ & $\begin{array}{c}\text { Candida tropicalis } \\
\text { MTCC 184 }\end{array}$ & $\begin{array}{c}\text { Aspergillus niger } \\
\text { MCIM 545 }\end{array}$ & $\begin{array}{c}\text { Aspergillus clavatus } \\
\text { MTCC 1323 }\end{array}$ \\
\hline & ZI (MIC) & ZI (MIC) & ZI (MIC) & ZI (MIC) \\
$\mathbf{6}$ & - & $15.4(20)$ & - & $14.4(20)$ \\
$\mathbf{8}$ & $17.1(25)$ & - & - & - \\
$\mathbf{1 3 a}$ & $15.3(20)$ & $16.8(20)$ & $14.4(20)$ & $12.4(20)$ \\
$\mathbf{1 3 b}$ & $\mathbf{1 3 . 4 ( 1 5 )}$ & $13.7(20)$ & $\mathbf{1 5 . 2 ( 1 5 )}$ & $\mathbf{1 3 . 1 ( 1 5 )}$ \\
$\mathbf{1 3 c}$ & $17.4(20)$ & $13.8(20)$ & $16.6(20)$ & $11.4(20)$ \\
$\mathbf{1 4 a}$ & $13.5(20)$ & $16.2(20)$ & $16.3(25)$ & $15.3(20)$ \\
$\mathbf{1 4 b}$ & - & $16.4(20)$ & - & $14.4(25)$ \\
$\mathbf{1 4 c}$ & - & $17.4(20)$ & - & $13.4(20)$ \\
$\mathbf{1 4 d}$ & $19.1(25)$ & $\mathbf{1 5 . 8}(\mathbf{1 0})$ & $\mathbf{1 4 . 6 ( 1 0 )}$ & $\mathbf{1 7 . 6}(\mathbf{1 5})$ \\
$\mathbf{1 6}$ & $15.4(20)$ & $16.8(20)$ & $17.2(20)$ & $13.4(20)$ \\
$\mathbf{1 7}$ & - & $16.4(20)$ & - & $17.7(20)$ \\
Gris. & $16.8(05)$ & $17.3(05)$ & $16.9(05)$ & $17.6(05)$ \\
\hline
\end{tabular}

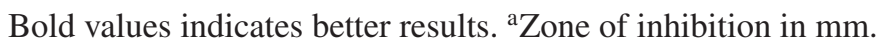

${ }^{\mathrm{b}}$ Minimum inhibitory concentration in $\mu \mathrm{g} / \mathrm{mL}$.

${ }^{c}$ n.t. not tested.

Compound 14a exhibited excellent antibacterial activity against gram-positive $B$. subtilis and gramnegative $E$. coli when compared with reference drug Streptomycin. While 17 showed comparable activity against only gram-negative $E$. coli in comparison with reference drug Streptomycin. On the other hand, compounds 13a and 14b showed good activity against gram-positive $B$. subtilis and gram-negative $E$. coli bacteria, respectively. However, compounds $6,8,13 b, 14 c$ and 16 showed comparatively weak activity against gram-positive $B$. subtilis and gram-negative $E$. coli bacteria. Compound $\mathbf{1 4 d}$ was proven to be comparable antifungal agent against $C$. tropicalis, A. niger and A. clavatus and compounds 13a, 13b and 14a illustrate good activity against $C$. albicans, $C$. tropicalis, $A$. clavatus and $A$. niger. The remaining compounds were found to have moderate activity against the tested organisms and some of the compounds were found to be inactive (indicated by - sign).

The variation in biological efficacy of tested compounds $6,8,13 a-b, 14 a-d, 16$ and 17 might be due to their structural variations. In particular, compounds $\mathbf{1 4 a}$ and $\mathbf{1 4 d}$ containing dioxopyrrolidine, dioxo-isoindol alicyclic moieties and $\mathbf{1 7}$ with dihydrofuro-pyrido moiety might be the reason for excellent activity (Scheme 6). Thus, presence of these functional groups could be useful for synthesis of new derivatives with better potency.

\section{Conclusions}

Suitably functionalized pyrazolo[1,5- $a$ ] pyrimidines were successfully utilized for the synthesis of new pyrazolo

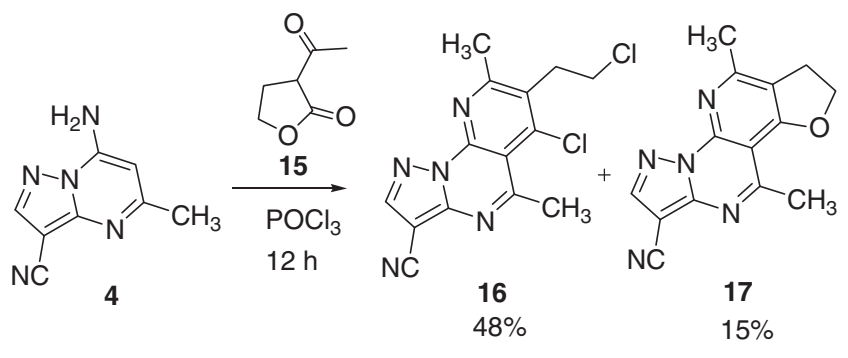

Scheme 6. Synthesis of pyrazolo-pyrido-pyrimidine $\mathbf{1 6}$ and dihydrofuro-pyridopyrazolo-pyrimidine 17.

$[1,5-a]$ pyrimidine annulated heterocycles. The recyclable, nonvolatile deep eutectic solvents have been adopted for the synthesis of dioxopyrrolidinylamino-pyrazolopyrimidines (14a-b) dioxoisoindolinylamino-pyrazolopyrimidines $(\mathbf{1 4 c - d})$, replacing less attractive solvents (for example acetic acid), with increased yields and reduced reaction times. The synthesized heterocycles were obtained by operationally simple, inexpensive and efficient methods in moderate to excellent yields. This method is currently being extended with the goal of generating a small library of fused pyrazolo[1,5- $a$ ] pyrimidines. Synthesized compounds were evaluated for antimicrobial activity. It was found that compound 14a is a good antibacterial agent and $\mathbf{1 4 d}$ is an excellent antifungal agent.

\section{Supplementary Information (SI)}

All additional information pertaining to characterization of the compounds using synthesis of pyrazolo[1,5a]pyrimidine derivatives (Schemes S1-6), 1H-NMR spectra (Figures S1, 3, 4, 7, 9, 11, 13, 15, 17, 19, 20, 22, 
24, 26), Mass spectrum (Figure S6), 13C-NMR spectra (Figures S2 , 5, 8, 10, 12, 14, 16, 18, 21, 23, 25, 27) are given in Supplementary Information. The recovery and recycling of deep eutectic solvent (Table S1), Optimization of solvent and catalysts for the synthesis of dioxo pyrrolidones and dioxoisoindol (Table S2), antibacterial activity of compounds (Table S3) and antifungal activity of compounds (Table S4) are also given in the Supporting Information, available at www.ias.ac.in/ chemsci.

\section{Acknowledgements}

MJ is thankful to CSIR (Emeritus Scientist Scheme) for the financial assistance. Authors thank Principal, KTHM College, Nashik 422 002, India for laboratory facilities.

\section{References}

1. George C F P 2001 Lancet. 3571623

2. Stefano A, Anna A, Maurizio B, Alessandra T, Francisco O, Silvia S, Chiara B and Matilde Y 2010 Chem. Med. Chem. 51242

3. Curran K J, Verheijen J C, Kaplan J, Richard D J, Toral-Barza L, Hollander I, Lucas J, Ayral-Kaloustian S, Yu K and Zask A 2010 Bioorg. Med. Chem. Lett. 20 1440

4. Zask A, Verheijen J C, Curran K, Kaplan J, Richard D J, Nowak P, Malwitz D J, Brooijmans N, Bard J and Svenson K 2009 J. Med. Chem. 525013

5. Manetti F, Santucci A, Locatelli G A, Maga G, Spreafico A, Serchi T, Orlandini M, Bernardini G, Caradonna N P and Spallarossa A 2007 J. Med. Chem. 505579

6. Schenone S, Bruno O, Ranise A, Bondavalli F, Brullo C, Fossa P, Mosti L, Menozzi G, Carraro F and Naldini A 2004 Bioorg. Med. Chem. Lett. 142511

7. Traxler P, Bold G, Frei J, Lang M, Lydon N, Mett H, Buchdunger E, Meyer T, Mueller M and Furet P 1997 J. Med. Chem. 403601

8. Ballell L, Field R A, Chungc G A C and Youngc R J 2007 Bioorg. Med. Chem. Lett. 171736

9. Gudmundsson K S, Johns B A and Weatherhead J 2009 Bioorg. Med. Chem. Lett. 195689
10. Rashad A E, Hegab M I, Abdel-Megeid R E, Micky J A and Abdel-Megeid F M E 2008 Bioorg. Med. Chem. 16 7102

11. Frizzo C P, Scapin E, Campos P T, Moreira D N and Martins M A P 2009 J. Mol. Struct. 933142

12. Novinson T, Bhooshan B, Okabe T, Revankar G R, Wilson H R, Robins R K and Senga K 1976 J. Med. Chem. 19512

13. Senga K, Novinson T, Wilson H R and Robins R K 1981 J. Med. Chem. 24610

14. Di Grandi M J, Berger D M, Hopper D W, Zhang C, Dutia M, Dunnick A L, Torres N, Levin J I, Diamantidis G and Zapf C W 2009 Bioorg. Med. Chem. Lett. 196957

15. Ahmed O M, Mohamed M A, Ahmed R R and Ahmed S A 2009 Eur. J. Med. Chem. 443519

16. Heathcote D A, Patel H, Kroll S H B, Hazel P, Periyasamy M, Alikian M, Kanneganti S K, Jogalekar A S, Scheiper B and Barbazanges M $2010 \mathrm{~J}$. Med. Chem. 538508

17. Fraley M E, Rubino R S, Hoffman W F, Hambaugh $\mathrm{S}$ R, Arrington K L, Hungate R W, Bilodeau M T, Tebben A J, Rutledge R Z and Kendall R L 2002 Bioorg. Med. Chem. Lett. 123537

18. Petroski R E, Pomeroy J E, Das R, Bowman H, Yang W, Chen A P and Foster A C 2006 J. Pharmacol. Exp. Ther. 317369

19. Bantwal S and Manjathuru M 2006 Bioorg. Med. Chem. Lett. 142040

20. Sherif A F 2010 Bioorg. Med. Chem. 182767

21. Agarwal R, Sumran G and Garg N 2011 Eur. J. Med. Chem. 463038

22. Jorda R, Havlícek L, McNae I W, Walkinshaw M D, Voller J, Sturc A, Navrátilová J, Kuzma M, Mistrík M, Bártek J, Strnad M and Krystof V 2011 J. Med. Chem. 542980

23. Wang S Q, Fang L, Liu X and Zaho K 2004 Chin. Chem. Lett. 15885

24. Singh B and Lobo H 2011 Catal. Lett. 141178

25. Pawar P M and Jarag K J 2011 Green Chem. 132130

26. Abott A and Capper G 2003 Chem. Commun. 70

27. Chikhalikar S, Bhawe V, Ghotekar B, Jachak M and Ghagare M 2011 J. Org. Chem. 763829

28. Chiklikar S, Bhawe V, Jachak M and Ghagare M 2011 Eur. J. Org. Chem. 426085

29. Rote R, Shelar D, Patil S and Jachak M 2011 Org. Prep. Proced. Int. 43457

30. Balwant S and Ganpati S 2011 Catal. Lett. 141178 